\title{
EDITORIAL
}

\section{Um novo projeto da SBF: Física para o Brasil \\ Pensando o futuro do ensino de física no País}

A Sociedade Brasileira de Física (SBF) está elaborando o Física para o Brasil cujo objetivo é "formular propostas que possam nortear o desenvolvimento da física no Brasil no decênio 2005-2015 e promover sua inserção na vida do País.” A Comissão formuladora do projeto, formada por representantes de várias sub-áreas da física e das diversas regiões do País, se compromete a promover discussões com a comunidade de físicos para conhecer suas opiniões, anseios e propostas sobre, entre outras, a priorização de áreas para o referido decênio. Acreditamos que, considerando a atual situação periclitante e as perspectivas pouco otimistas, o ensino de física em todos os níveis deverá ser priorizado.

A Comissão conta com a participação de vários membros da comunidade que têm mostrado preocupação com o ensino de física e dedicado parte de seu tempo à melhoria do mesmo atuando em várias frentes. Os dois representantes da área de ensino de física são Anna Maria Pessoa de Carvalho e Susana de Souza Barros.

Vários estudos com objetivos similares já foram elaborados pela SBF. O primeiro documento sobre a situação da física no Brasil foi produzido em $1975^{1}$, fruto de uma pesquisa junto aos profissionais de física sobre a situação desta ciência no Brasil. Em 1987, um segundo levantamento foi publicado ${ }^{2}$, contendo a descrição dos grupos de pesquisa e seus líderes, as áreas de atuação e os projetos em desenvolvimento. Embora os documentos contenham informações valiosas que nos permitem traçar uma retrospectiva histórica da física no País, não foi possível realizar uma avaliação global nem fazer projeções. Na sub-área "Ensino de Física", representada na Comissão por Luis Carlos Menezes, os programas de pós-graduação (IFUSP e IFUFRGS) e as linhas de pesquisa e projetos educacionais estão descritos sucintamente. $\mathrm{O}$ número de pesquisadores formados na área era de 12 doutores $^{3}$ e 75 mestres e cerca de 100 pós-graduandos desenvolviam pesquisas. Importante ressaltar, naquela época, o expressivo suporte do Programa de Apoio ao Desenvolvimento Científico e Tecnológico (PADCT/MCT) com seu sub-projeto Educação para a Ciência.

Três anos depois, a SBF lança o Física no Brasil na Próxima Década ${ }^{4}$, em que foi possível, além de atualizar os dados anteriores, realizar uma análise prospectiva com a apresentação de novos projetos, recursos humanos disponíveis e necessidade de infra-estrutura física e financeira que permitisse a viabilização bem sucedida dos projetos em desenvolvimento e implementação dos novos. O estudo sobre a área "Ensino de Física", coordenado por Susana de Souza Barros, é mais abrangente contemplando aspectos relevantes do ensino de física, problemas e perspectivas da pesquisa em ensino de física e, ao final, encaminhando várias sugestões e recomendações.

Passados 13 anos após esse estudo, torna-se imperativo que o novo levantamento se inicie pela avaliação do atual estágio do ensino de física no País e quais propostas e recomendações, então apresentadas, foram implementadas.

O estudo feito em 1990 levantou a questão da interdisciplinaridade e das metodologias, intrínsecas à área da pesquisa em ensino de física, que, na época, era considerada como um "corpo estranho" dentro dos institutos e departamentos de física. Hoje, pode se considerar que esse problema está parcialmente superado e, na atualidade, existe uma abertura positiva para a formação de novos grupos de pesquisa na área e um interesse de alguns pesquisadores da física "dura" em considerar o ensino de física como um objeto de estudo, com métodos próprios, que deve ser levado a sério. Observa-se, no entanto, que ainda são poucos os institutos de física que reservam vagas específicas para especialistas na área de ensino de física.

\footnotetext{
${ }^{1}$ Vanya Mundim Sant'Anna, A Situação da Física no Brasil - $1^{a}$. Parte: Os trabalhadores em Física no Brasil, relatório de pesquisa.

${ }^{2}$ Sociedade Brasileira de Física, A Física no Brasil, São Paulo (1987).

${ }^{3} \mathrm{Na}$ realidade, o número de doutores atuando na área era bem maior, mas originalmente formados em outras sub-áreas da física.

${ }^{4}$ Sociedade Brasileira de Física, A Física no Brasil na Próxima Década, São Paulo (1990).
} 
Quanto ao caráter aplicado, observa-se que a estagnação do ensino de física na escola, observada ao longo dos diversos levantamentos, carece ainda de mudanças de base, ficando sem solução aspectos da transferência do conhecimento adquirido para o sistema educacional nos três níveis de ensino.

A formação do professor, responsabilidade intrínseca à universidade, deixa muito a desejar, tanto em qualidade quanto em quantidade, sendo que o número de professores formados anualmente é sabidamente, pelo menos, uma ordem de grandeza menor que o necessário para atender a atual demanda de um ensino médio obrigatório. Os diagnósticos levantados na época permanecem quase que inalterados no que se refere à problemática da escola pública, mesmo considerando que houve um avanço substancial com a formulação dos Parâmetros Curriculares Nacionais (PCN). A implementação desta proposta, apesar de ter penetrado no imaginário do professor, ainda enfrenta sérias dificuldades ${ }^{5}$ e entraves de um sistema desestimulador, carente de lideranças, e com vícios que devem ser erradicados com a firmeza e seriedade que a situação exige. Mesmo com alguns estudos feitos, a já antiga intenção de introduzir a física moderna na escola média, e no ciclo básico superior, ainda está longe de ser concretizada.

Quanto à educação continuada dos professores, devemos reconhecer que, apesar dos avanços quantitativos e expressivos esforços das autoridades educacionais, agências de financiamento e instituições de ensino superior, seus efeitos sobre o sistema educacional não são ainda visíveis. As causas são complexas, porque sem a solução dos problemas de infraestrutura escolar, tanto quanto trabalhistas do professor, não haverá formação continuada eficiente que contribua para o seu aprimoramento profissional.

Quanto à formação do professor-formador, tanto licenciado quanto bacharel, a proposta de adicionar uma componente pedagógica aos cursos de bacharelado e de pós-graduação (PG) ainda não foi implementada. Somente agora a CAPES exige dos programas que os estudantes da PG tenham alguma experiência didática (sabe-se lá em que grau de eficiência está se realizando). Quanto à pesquisa em ensino, a última década assistiu ao atendimento de várias recomendações. Novos grupos foram formados, o número de programas de PG duplicou. A CAPES atendeu à aspiração da comunidade de ensino de física, criando o Comitê de Educação em Ciências e Matemática e o programa de mestrado profissional que propicia novo alento para a formação de quadros capacitados para exercer liderança no sistema educacional.

Mesmo com uma fração considerável da comunidade dos físicos ciente da necessidade de uma educação de qualidade e de sua própria responsabilidade para a solução dos problemas, estamos ainda muito longe de enxergar a luz no fim do túnel. Certamente teremos todos os profissionais da física que participar de um grande mutirão, para reverter o atual quadro de falência educacional.

Por que não começar participando ativamente deste estudo prospectivo sobre a situação atual da física no Brasil?

\footnotetext{
${ }^{5}$ Elio C. Ricardo, Implementação dos PCN em Sala de Aula: Dificuldades e Possibilidades, Física na Escola, v. 4, n. 1, p. 8 (2003).
} 